Arnljot Tveit (f. 1958) er spesialist i indremedisin og avdelingssjef samt prosjektleder for flere forskningsprosjekter, ved Bærum sykehus, Oslo universitetssykehus og Universitetet i Oslo.

Oppgitte interessekonflikter: Forfatter har mottatt foredragshonorar/ konsultasjonshonorar fra Bristol-Meyer-Squibb, Bayer, MSD, SanofiAvensis, Boehringer-Ingelheim, Nycomed og BMS/Pfizer.

David Russell (f. 1948) er professor og lege ved Klinikk for kirurgi og nevrofag, Oslo universitetssykehus.

Oppgitte interessekonflikter: Forfatter har mottatt foredragshonorar/ konsultasjonshonorar fra Boehringer-Ingelheim, BMS/Pfizer og Bayer.

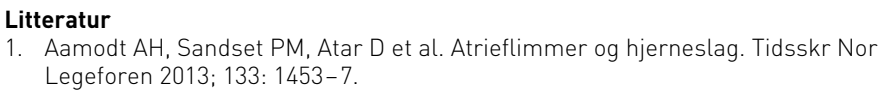

1. Aamodt AH, Sandset PM, Atar $D$ et al. Atrieflimmer og hjerneslag. Tidsskr Nor Legeforen 2013; 133: 1453-7.

\section{Bakterier og andre mikroorganismer}

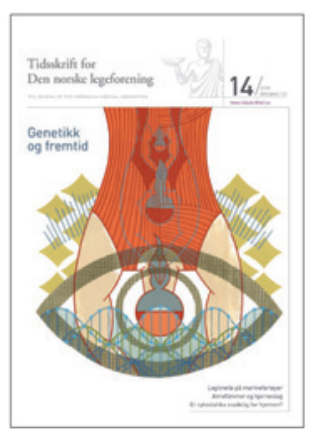

I sitt innlegg i Språkspalten i Tidsskriftet nr. 14/2013 (1) spør Øystein HaarklauJohansen hvorfor Tidsskriftet ikke skriver bakterienavn korrekt. Han gir selv et eksempel på hvordan fullt navn skal skrives, inkludert genus og spesies Staphylococcus aureus - og deretter forkortes $-S$. aureus. Bruk av forkortelsen forutsetter at navnet er skrevet fullt ut første gang. Faktisk skal det alltid forkortes videre $i$ et manuskript, unntatt når det gjentas i kapitteloverskifter.

Bruk av kursiv er i det ovenstående eksemplet obligatorisk. Forskjellig skrifttype benyttes for andre nivåer i bakterienes systematikk. Dette er gjennomført for alle kjente bakterienavn i det store referanseverket Bergey's Manual of Systematic Bacteriology. Forslag til nye navn blir publisert i egnede internasjonale tidsskrifter for senere å bli vurdert for inntak i Bergey.

For virus er taksonomien (navn og systematikk) på langt nær så oversiktlig.

Det er en betimelig sak Haarklau-Johansen tar opp i sitt innlegg. Flere av oss har tidligere tatt opp samme sak med Tidssskriftets redaksjon uten å få svar. Problemstillingen burde være såre enkel: Redaksjonen trenger ikke å lage egne retningslinjer, fordi det ikke hersker noen tvil om hvordan bakterienavn skal skrives. Forfattere og fagvurderere forutsetter korrektur i overenstemmelse med Bergey.

Tidsskriftredaksjonen inntar i dag en særstilling i det å rutinemessig kreve at godkjente navn skal skrives feil. Når redaksjonen i sitt svar til Haarklau-Johansen sier at bakterienavn kan skrives på mange måter, er dette for så vidt korrekt, men i så tilfelle når? Skrivemåten er strikt funksjon av hvilken betydning man ønsker å få frem. Genusnavn, f.eks. Staphylococcus, skal i regelen aldri stå alene, men følges av spesiesnavnet, f.eks. aureus. Å skrive «gruppen stafylokokker» eller «gruppen staphylococcus» (alt uten kursiv) er helt greit, gitt at sånn passe omtrentlighet er på sin plass $i$ en sammenheng. Fravær av korrekt taksonomi gjør fort at et manuskript oppfattes som useriøst.

Hva redaksjonen i Tidsskriftet synes å ha tenkt mindre på, er hvordan en artikkel med systematisk feilskrevet taksonomi vil fremstå i forfatterens skarpt redigerte CV. Artikkelen kan ikke gjøre krav på å være vitenskapelig utarbeidet og listes under «Videnskapelige publikasjoner». Den vil eventuelt gå under «Annet»- det som kliniske mikrobiologer vil kalle journalistikk og håpe at er en slags folkeopplysning.
Å skrive E coli O157 i Tidsskriftets ordliste når det ikke koster mer å skrive Escherichia coli $\mathrm{O} 157$ er kanskje god populisme, men like fullt en faglig flause.

\section{Bjørn P. Berdal}

bberdal@gmail.com

Bjørn P. Berdal (f. 1941) er professor i medisinsk mikrobiologi. Ingen oppgitte interessekonflikter.

Litteratur

1. Johansen $\emptyset \mathrm{H}$. Bakterier og andre mikroorganismer. Tidsskr Nor Legeforen 2013; 133: 1472 .

Dette er en redigert versjon av debatten, publisert som rask respons på nett 27.8.2013. http://tidsskriftet.no/article/3037008/

\section{Taushetsplikt, fiksjon og virkelighet}

I sin anmeldelse av min bok Min DNAgbok i Tidsskriftet nr. 14/2013 (1) beskylder Hanne Støre Valeur meg for å bryte taushetsplikten. Hun skriver:

«Etter å ha uttalt seg utvetydig om verdien av taushetsplikt og personvern, og i tillegg rettet skarp kritikk mot Knausgårds litterære utlevering av sine nærmeste, overrasker det meg at forfatteren selv serverer lett gjenkjennbare beskrivelser av pasienter fra egen klinisk hverdag i sine dagboksnotater - uten å presisere om dette er gjort med tillatelse fra pasientene.»

Pasienthistoriene jeg har med i boken, er oppdiktet. Ingen av mine virkelige pasienter kan kjenne seg igjen, for jeg har ikke skrevet om dem. I undervisning og i medisinske artikler publiserer leger ofte kasuistikker der pasientens kjønn, alder, yrke osv. er endret, slik at vedkommende ikke skal kunne gjenkjennes. Da jeg arbeidet med boken, vurderte jeg å gjøre dette, men kom frem til at det var bedre, og tryggere, å dikte opp pasienthistorier, basert på ti års erfaring som genetiker. Pasienthistoriene i boken baserer seg på diagnoser, dilemmaer, situasjoner og følelser fra utallige møter med pasienter. Men det er altså fiksjon.

Brudd på taushetsplikten er alvorlig, og en slik beskyldning kan jeg ikke ha hengende på meg.

\section{Ellen Økland Blinkenberg}

ellen.okland.blinkenberg@helse-bergen.no

Ellen $\emptyset$ kland Blinkenberg (f. 1967) er lege ved Senter for medisinsk genetikk og molekylærmedisin.

Ingen oppgitte interessekonflikter.

\section{Litteratur}

1. Valeur HS. Genetikk til folket. Anmeldelse av: Blinkenberg EØ. Min DNAgbok. Tidsskr Nor Legeforen 2013; 133: 1474.

Dette er en redigert versjon av debatten, publisert som rask respons på nett 9.8.2013. http://tidsskriftet.no/article/3037114/

\section{H.S. Valeur svarer:}

I anmeldelsen påpeker jeg at jeg savner en presisering av om pasienthistoriene som refereres i boken, er gjengitt med tillatelse. Pasienthistoriene presenteres i forfatterens personlige og daterte dagboknotater hvor hun blant annet forteller om hva hun har opplevd på jobben, og det er derfor ikke selvinnlysende at disse er fiksjon. Som leser ble jeg sittende igjen med en uvisshet rundt bakgrunnen for pasienthistoriene. Forfatteren kunne ha ryddet en slik uklarhet av veien ved å opplyse om at pasienthistoriene var oppdiktet.

Hanne Støre Valeur

hanne.store.valeur@legeforeningen.no 